\title{
Lydia Zapata (1965-2015), un recuerdo sentido a una excelente investigadora y compañera inseparable
}

\section{Lydia Zapata (1965-2015): a heartfelt remembrance of an excellent scholar and an inseparable companion}

\author{
Leonor Peña-Chocarro (*) \\ Xavier Terradas (**)
}

Conocí a Lydia hace ya 25 años, cuando llegó al Instituto de Arqueología de Londres con una beca de la Association for Cultural Exchange del propio instituto, mientras yo (LPCH), con otra beca, descubría el infinito mundo de la arqueobiología. De la mano de Gordon Hillman, nuestro gran maestro, aprendimos juntas los misterios de la arqueobotánica y la pasión por una disciplina que entonces se iniciaba en la Península Ibérica. Las clases, seminarios, conferencias, las inagotables lecturas, así como las interminables horas delante del microscopio, observando, explorando, forjaron en las dos el deseo tenaz de dedicarnos a la investigación. Fue un año rico de experiencias, de incontenibles ganas de hacer cosas, desarrollar proyectos y planear futuros. Desde el primer día supimos que nuestros caminos transcurrirían juntos, y así fue, hasta el pasado 4 de enero cuando un maldito tumor cerebral nos la arrebató a los 49 años.

Lydia nace en Bilbao (1965), se licencia en Prehistoria por la Universidad de Deusto (1988) y se doctora en la Universidad del País Vasco (UPV 1999) con una tesis titulada Origen de la agricultura en el País Vasco y transformaciones en el paisaje: análisis de restos vegetales arqueo-

(*) Escuela Española de Historia y Arqueología en Roma (EEHAR), Consejo Superior de Investigaciones Científicas (CSIC). Via Santa Eufemia 13. 00187 Roma. Italia.

Correo e.: leonor.chocarro@csic.es

(**) Institució Milà i Fontanals-CSIC, Consejo Superior de Investigaciones Científicas (CSIC). C/ Egipcíaques 15. 08001 Barcelona. Correo e.: terradas@imf.csic.es.

Recibido 23-III-2015; aceptado 4-VIII-2015. lógicos co-dirigida por sus maestros I. Barandiarán y J. Loidi. Este trabajo, publicado en 2002 en Kobie, constituyó un importante hito para la Prehistoria vasca contribuyendo de forma importante a reformular las entonces imperantes teorías sobre la tardía adopción de la agricultura en la región. En él abordaba también la importancia de la recolección en la subsistencia humana, un tema que desarrolló con mayor intensidad en los últimos años, y que en su tesis esboza de manera prometedora. Al estudio de los restos carpológicos, Lydia añadió el de los carbones, con un magnífico análisis sobre la antropización del medio y la evolución de los bosques holocenos y de su aprovechamiento por parte de las comunidades prehistóricas. La combinación de la carpología y la antracología ha sido una de las características de su investigación, demostrando su excelente formación y la capacidad para trabajar con diferentes tipos de materiales botánicos. Tal fue su empeño en desarrollar conjuntamente estas dos líneas de investigación que con frecuencia impuso ambas a los numerosos estudiantes que pasaron por su laboratorio.

Lydia desde Bilbao, yo desde Madrid, iniciamos entonces nuestra campaña personal para implantar la recogida de muestras arqueobotánicas en los yacimientos de amigos y colegas. Visitamos muchos lugares, recorrimos miles de kilómetros con nuestras máquinas de flotación y procesamos toneladas de sedimento. Desde la Universidad del País Vasco y, en concreto, desde su Laboratorio de Arqueobotánica, Lydia participa entonces en numerosos proyectos de investigación sobre la 
transición mesolítico-neolítico, los orígenes de la agricultura, la evolución del paisaje y, en general, sobre la subsistencia de las comunidades humanas, convirtiéndose rápidamente en un punto de referencia internacional.

Durante dos años Lydia realiza una estancia post-doctoral en la Universidad de Cambridge y posteriormente se incorpora como becaria a la UPV. A esto le sigue un breve paso por el CSIC con un I3P, un contrato Ramón y Cajal, y finalmente una plaza de profesora titular en la UPV en 2007.

Son años intensos, inmensamente felices, en los que participamos en muchos proyectos, y en lo que nos apuntábamos a lo que nos parecía interesante... que era casi todo. Recorrimos la Península Ibérica y Marruecos a la búsqueda de trigos prehistóricos y agriculturas pre-industriales en unos viajes que, a menudo, recordábamos y que nos dejaron una huella indeleble. Horas infinitas de conversación en lo alto de un monte, de trabajo etnográfico con nuestros agricultores, o como remarcaba siempre Lydia, nuestras agricultoras. Asturias (Fig. 1), Marruecos, las serranías andaluzas nos ofrecieron la posibilidad de explorar el uso de las plantas entre las comunidades rurales y descubrir, de primera mano, el enorme potencial de la investigación etnográfica para interpretar el registro arqueológico. La fascinante experiencia de los días y semanas pasados con mujeres recolectoras, agricultoras, artesanas y ceramistas nunca le abandonó, y a menudo revivíamos las

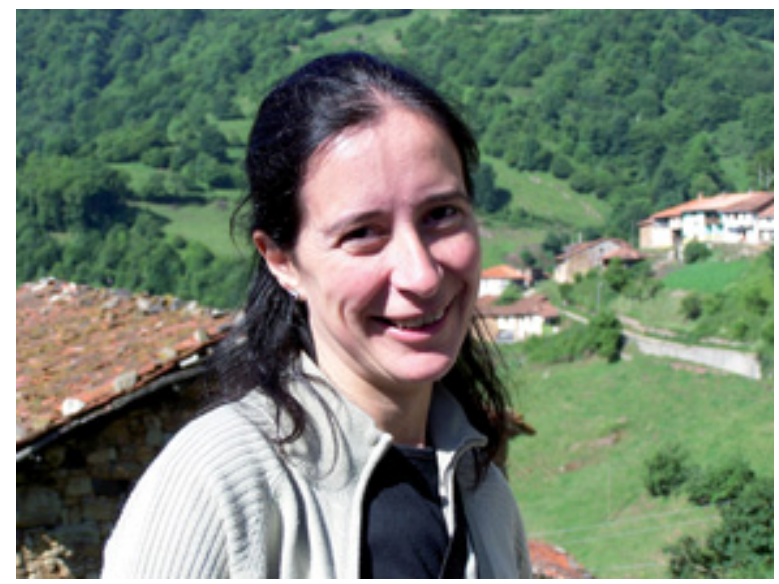

Fig. 1. Lydia en Bandujo (Asturias) durante la reunión del proyecto europeo EARTH, mayo 2005 (foto Leonor Peña Chocarro). infinitas anécdotas, muchas demenciales, de aquellos años. Compartimos ilusiones, ideales, muchas risas. Trabajar junto a ella ha sido la más grata de las experiencias (LPCH).

La guerra en Siria interrumpió su participación en los proyectos de investigación internacionales que se desarrollaban en Homs, al Oeste de Siria y, sobre todo, en la llanura basáltica de Leja, al Sur de Siria. Allí tuvo la oportunidad de trabajar con poblaciones de cereales silvestres y de estudiar muestras de los primeros trigos domésticos en el yacimiento de Qarassa. Aunque nos conocíamos desde unos años antes y pese a disfrutar de amigos comunes, nunca antes habíamos tenido la oportunidad de trabajar juntos (XT). Congeniamos enseguida, nuestras mutuas circunstancias personales propiciaron que nuestros caminos se encontraran y se unieran ineludiblemente. Desde Jeftelik tuve el privilegio de compartir la vida de Lydia, sus anhelos personales y científicos, su amor, compañía y complicidad. Más allá de su valía científica, nunca dejó de sorprenderme la estima que despertaba entre sus colegas de cualquier país, institución y formación científica, lo que habla mucho y claro de sus cualidades humanas, más allá de su valía profesional y científica. Por todo ello siempre me sentí como un ser privilegiado. Los meses en los que estuvo convaleciente no dejó de sorprenderme su capacidad de lucha, la entereza con la que afrontó sus/nuestros miedos $\mathrm{y}$, pese a la incertidumbre de su salud, que siempre tuviera una sonrisa y unas palabras afables y cariñosas para los que la acompañamos en su enfermedad.

La investigación de Lydia ha estado, fundamentalmente, orientada al estudio del aprovechamiento de los recursos vegetales durante la Prehistoria con trabajos también de periodos posteriores como nuestra investigación sobre el puerto romano de Irún o su estudio de la Catedral de Vitoria. Además de seguir investigando sobre las primeras comunidades campesinas, en los últimos años, dedicó tiempo y esfuerzo a indagar sobre la dieta vegetal de los cazadores-recolectores, un tema que le llevó a solicitar un magnífico proyecto al prestigioso European Research Council (ERC), que consiguió de manera brillante a finales de 2013, culminando, a pesar de las dificultades, una trayectoria investigadora impecable y de enorme impacto tanto en la Península Ibérica como en el ámbito internacional. 
Directora de 4 tesis doctorales, autora de más de 100 trabajos de los que gran parte han sido publicados en revistas internacionales, directora de varios proyectos de investigación entre los que destaca su último logro europeo, así como directora de excavaciones como Pico Ramos, Koba Ederra o Baltzola, Lydia nos deja un legado científico modélico, difícilmente superable, de gran rigor científico. Pero, sobre todo, Lydia deja un vacío irremplazable, un recuerdo inolvidable y una profunda huella en quienes tuvimos la inmensa suerte de entretejer nuestra vida con la suya. Su entusiasmo por cada nueva aventura, su proximidad, complicidad y calidez humana, su amor, su amistad profunda y gran generosidad han sido un regalo mágico. Más allá del dolor y el vacío de su pérdida, nos reconforta el haber compartido tantas y tan imperecederas vivencias con ella.

Ez adiorik Lydia. Zuganako maitasunak bizirik iraungo du betiko gure gogoan (Hasta siempre Lydia, te seguimos queriendo y no te olvidamos). 